\title{
The Comparison of Different Irrigation Systems to Remove Calcium Hydroxide from the Root Canal: A Systematic Review and Meta-Analysis
}

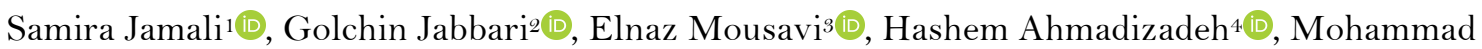 \\ Khorram $^{5}$ (D), Azad Jamee ${ }^{2}$ (D)
}

\begin{abstract}
${ }^{1}$ Department of Endodontics, Stomatological Hospital, College of Medicine, Xi'an Jiaotong University, Shaanxi, China. ${ }^{2}$ Department of Endodontics, Dental School, Urmia University of Medical Sciences, Urmia, Iran.

${ }^{3}$ Dental Sciences Research Center, Department of Endodontics, School of Dentistry, Guilan University of Medical Sciences, Rasht, Iran.

${ }^{4}$ Tehran University of Medical Sciences, Tehran, Iran.

${ }^{5}$ Golpayegan Health Center, Isfahan University of Medical Sciences, Isfahan, Iran.
\end{abstract}

Author to whom correspondence should be addressed: Samira Jamali, Department of Endodontics, Stomatological Hospital, College of Medicine, Xi'an Jiaotong University, Shaanxi 710004, PR China. Phone: +86 29 82655450. E-mail: samira.jamali90@yahoo.com.

Academic Editors: Alessandro Leite Cavalcanti and Wilton Wilney Nascimento Padilha

Received: 16 August 2019 / Accepted: 13 November 2019 / Published: 19 November 2019

How to cite this article: Jamali S, Jabbari G, Mousavi E, Ahmadizadeh H, Khorram M, Jamee A. The comparison of different irrigation systems to remove calcium hydroxide from the root canal: a systematic review and meta-analysis. Pesqui Bras Odontopediatria Clín Integr. 2020; 20:e5404. https://doi.org/10.1590/pboci.2020.017

\footnotetext{
Abstract

Objective: To examine the effect of a variety of irrigation systems on the removal of root canal $\mathrm{Ca}(\mathrm{OH})_{2}$ residues through meta-analysis and systematic review. Material and Methods: A search of relevant articles was systematically performed on databases of Medline, PubMed, Cochrane Library, Embase, ISI, and Google Scholar published from 2013 to 2019. Electronic title management was carried out by EndNote X9 software. Searches were based on the main keywords of "Irrigation Systems", "Calcium Hydroxide"," Root Canal”, "Self-adjusting File OR SAF”, “Conventional Irrigation”, "EndoVac System”, “Ultrasonic Irrigation” and "YAG Laser". Results: The studies investigated were found to lack any standardization concerning the irrigation method used or the measurement of outcomes; for instance, different studies used 5 or $10 \mathrm{~mL}$ of $2.5 \% \mathrm{NaOCl}$, or $5 \mathrm{~mL}$ of $5.25 \% \mathrm{NaOCl}$, or $0.5 \mathrm{~mL}, 3 \mathrm{~mL}$ and $10 \mathrm{~mL}$ of $17 \%$ EDTA. Conclusion: The effective techniques for the removal of root canal $\mathrm{Ca}(\mathrm{OH})_{2}$ were PUI, and SAF approaches.

Keywords: Endodontics; Root Canal Therapy; Root Canal Irrigants; Calcium Hydroxide.
} 


\section{Introduction}

The microorganisms' presence in root canals plays a key part in developing periapical diseases [1]. Root canal therapy is primarily conducted to create an environment where no residual organisms can survive by eliminating as many bacteria as possible from root canal systems [2]. Irrigation and instrumentation need to be supported by intra-canal medications to achieve the cited goal [3].

Given the antimicrobial activities, the capacity for inactivating bacterial endotoxins, and the biological properties associated with calcium hydroxide, $\mathrm{Ca}(\mathrm{OH})_{2}$, this substance is commonly used as an endodontic intra-canal medication [4] or a temporary medicament in root canal therapy. It was previously proposed that calcium hydroxide can be directly used in endodontics as a pulp capping agent [5]. For over 40 years, the calcium hydroxide has been employing as an antimicrobial agent. Some authors believe that it is probably the number one interappointment agent to eliminate the microbiota of the oral cavity [6].

It is assumed that the bacterial enzymes can be inactivated irreversibly due to the high $\mathrm{pH}$ value of this substance, which allows keeping for a long time [7]. Among these, three pathways have been mainly found to destroy bacteria in endodontics; the first is associated with the activity of calcium hydroxide because of the high value of its $\mathrm{pH}$, ion decomposition, and $\mathrm{OH}$ release in water [8]. The second pathway is related to $\mathrm{OH}$ - triggering peroxidation of lipid and destroys the microbial cell wall phospholipids. In the third pathway, the interaction between $\mathrm{Ca}(\mathrm{OH})_{2}$ and DNA molecules of the bacteria results in the segmentation of polynucleotide chains and so causes the loss of the genes, preventing the DNA replication and inactivating the microbial performance. The microbial endotoxin produced in the root canal is detoxicated via $\mathrm{Ca}(\mathrm{OH})_{2}[9]$. The water-based $\mathrm{Ca}(\mathrm{OH})_{2}$ containing substances having cellulose type thickener make it difficult to remove them from the root canals [10].

Calcium hydroxide can be eliminated from root canals using different methods [11]. Higher effectiveness has been reported for passive ultrasonic irrigation (PUI) to remove the root canal dentine debris compared to delivering the irritant with a syringe [12]. PUI is based on placing and activating a small file at the core of a previously shaped root canal so as to generate cavitation and acoustic streaming [13]. The PUI has been found to be more effective in eliminating the root canal $\mathrm{Ca}(\mathrm{OH})_{2}$ paste compared to the syringe delivery of irritants[14]. In addition, agitation with the master apical file was found to be more effective compared to the irritant only techniques the procedure in terms of removing the root canal $\mathrm{Ca}(\mathrm{OH})_{2}[15]$.

A review of the literature suggests different methods for the removal of root canal $\mathrm{Ca}(\mathrm{OH})_{2}$, including canal brush, PUI, rotary instrumentation and hand filing [13,16,17]; nevertheless, given the irregular channel structure, it is difficult to remove the root canal $\mathrm{Ca}(\mathrm{OH})_{2}[18]$. This irregularity becomes more problematic in certain methods. Residues remaining in irregularities or canal extensions after removing the medication from root canals with a file can only be removed with irrigation [19].

The purpose of this meta-analysis and systematic review was to examine the effect of a variety of irrigation systems on the removal of root canal $\mathrm{Ca}(\mathrm{OH})_{2}$ residues.

\section{Material and Methods}

Search Strategy

The electronic databases included Medline (Medical Literature Analysis and Retrieval System Online), PubMed, Cochrane Library, Embase, Institute for Scientific Information (ISI), and Google Scholar to search systematically the relevant studies published from January 2013 to August 2019 in the dental literature. Electronic title management was carried out by EndNote X9 software. Searches were based on the main 
keywords of "Irrigation Systems", "Calcium Hydroxide”," Root Canal”, Self-adjusting File OR SAF”, “Conventional Irrigation”, “EndoVac System”, “Ultrasonic Irrigation” and "YAG Laser.

\section{Study Inclusion and Exclusion Criteria}

The considered inclusion criteria in this study were as follows: 1) Articles evaluating the removal of calcium hydroxide, which was placed at root canal apical third as an intra-canal medicament; 2) Papers that compared ultrasonically activated irrigation with other irrigation methods; 3) Articles examining the cleaning effectiveness of irrigation devices; and 4) In-vitro studies, randomized controlled trials, Scanning Electron Microscopic Study, on the extracted fully formed teeth.

Quality Assessment Analysis

The included full-text articles were assessed qualitatively using the Cochrane collaborations' tool within two steps, including assessment by two independent authors in accordance with the published full-text articles (step I) and resolve of any disagreement through discussion method.

\section{Analysis Processes}

Comprehensive Meta-Analysis Stata 14.0 statistical software was used to evaluate the heterogeneity of RCTs, forest plots, and meta-analysis (considering a 95\% confidence interval and weighted mean difference).

\section{Results}

The preliminary analysis involved 225 articles. Two reviewers investigated all the available abstracts and titles and determined whether they were associated with the healing effect of various irrigation systems on removing calcium hydroxide. Articles were automatically included in the subsequent analysis when the data obtained from the abstracts and the titles were inadequate for determining the paper's relevance. The excluded studies from the list totaled 218 articles, and stricter exclusion criteria were based on investigating the seven articles remaining (Figure 1).

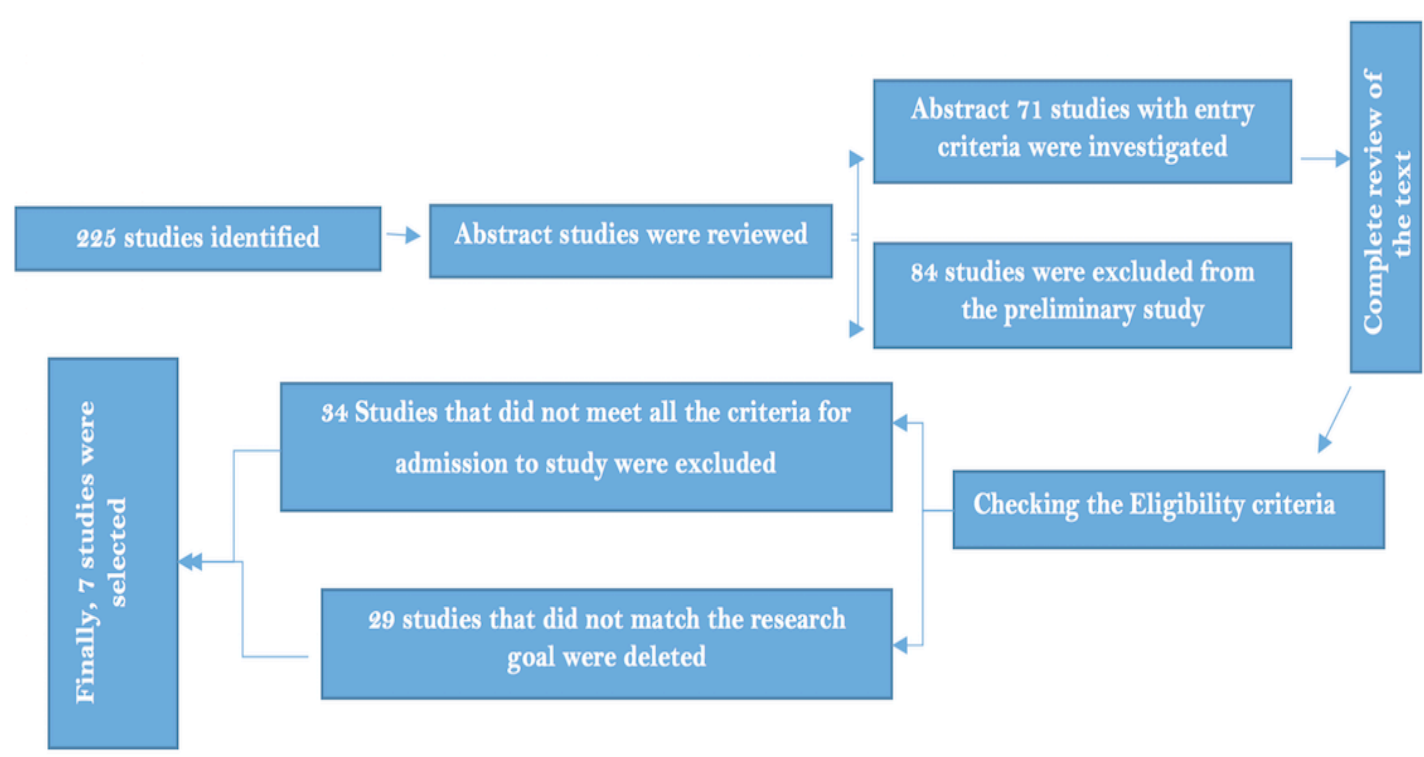

Figure 1. Study attrition diagram. 
The review studies about the number of patients, 51 patients were evaluated in this study, Quality score in all studies was Moderate.

The studies investigated were found to lack any standardization concerning the irrigation method used or the measurement of outcomes; for instance, different studies used five or ten $\mathrm{mL}$ of $2.5 \% \mathrm{NaOCl}$, or five $\mathrm{mL}$ of $5.25 \% \mathrm{NaOCl}$, or $0.5 \mathrm{~mL}, 3 \mathrm{~mL}$ and $10 \mathrm{~mL}$ of $17 \%$ EDTA. Moreover, differences were observed for different irrigation times. A study assessed outcomes by the use of an electron microscope, while other studies examined the outcomes under stereomicroscopes or utilizing micro-computed tomography scanning. Table 1 presents the features of the articles included. The trial sample sizes varied in terms of the number of teeth involved in the experimental group, ranging from seven to eighty-eight. The studies included were found to possess a moderate total risk of bias. The methods used in these studies were different in terms of the blinding of the teeth, the needle gauge of syringe irrigation, irrigation time, the irrigation needle insertion and the placement of ultrasonic file, the teeth type and ultrasonic tip model, the power, and type of the ultrasonic device.

Table 2 showed the success rate of different irrigation methods for the root canal $\mathrm{Ca}(\mathrm{OH})_{2}$ removal after extracting these data, the collected data were a meta-analysis.

According to the findings from the meta-analysis, no statistically significant difference was found between irrigation methods for the root canal $\mathrm{Ca}(\mathrm{OH})_{2}$ removal. More effective techniques for the root canal $\mathrm{Ca}(\mathrm{OH})_{2}$ removal in the apical part were SAF and Continuous PUI compared to EndoVac and other common irrigation methods (Figure 2).

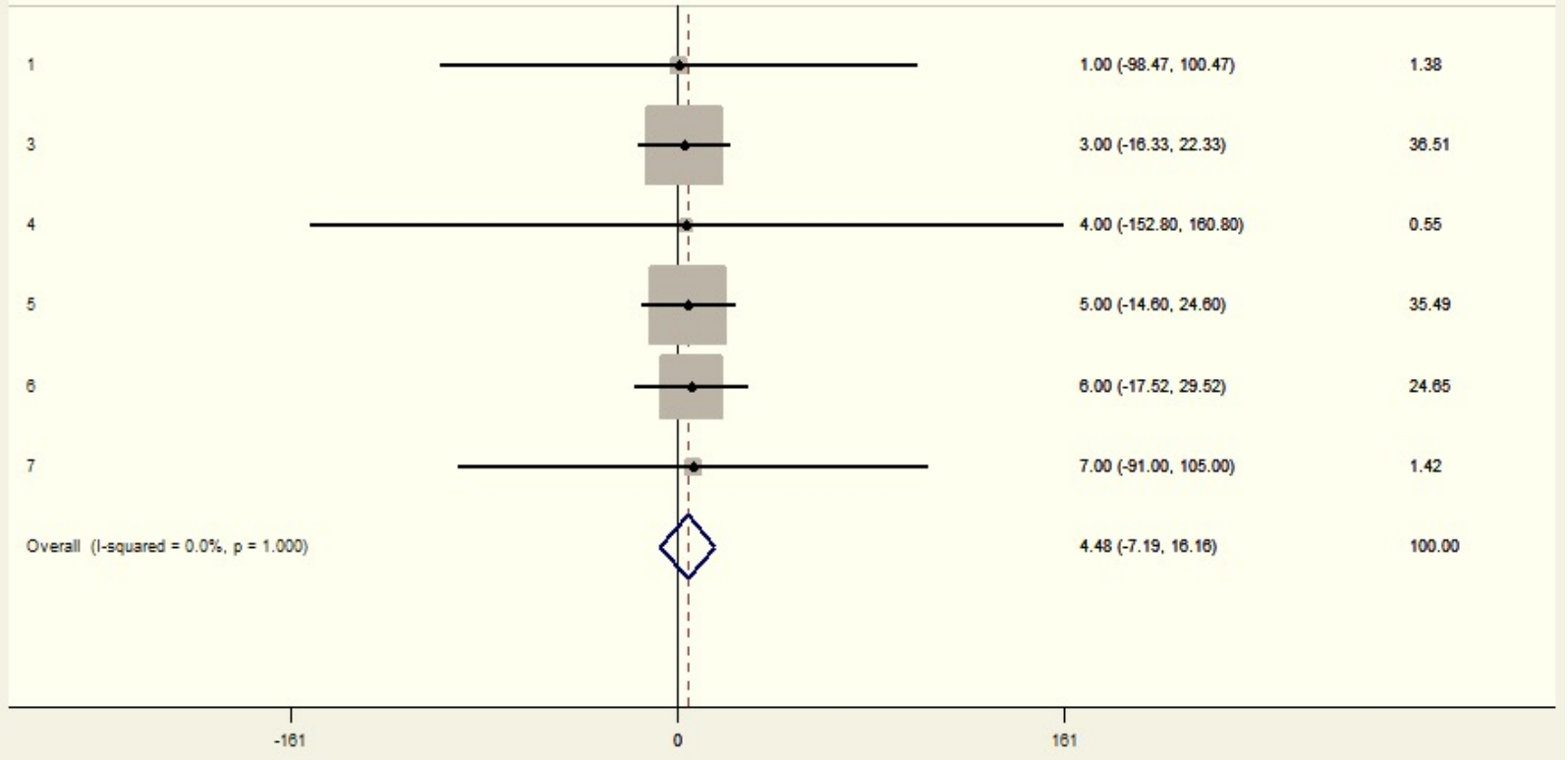

Figure 2. A meta-analysis forest plot including its various components. 


\section{Table 1. Characteristics of included studies.}

\begin{tabular}{|c|c|c|c|c|c|c|c|}
\hline Study & $\begin{array}{l}\text { Sample } \\
\text { Size } \\
(\mathbf{N})\end{array}$ & $\begin{array}{l}\text { Type of the } \\
\text { Teeth }\end{array}$ & Type of Intervention & $\begin{array}{l}\text { Type of } \\
\text { Calcium } \\
\text { Hydroxide }\end{array}$ & Irrigation Technique & $\begin{array}{l}\text { Evaluation } \\
\text { Method }\end{array}$ & Quality Score \\
\hline Kourti et al. [20] & 84 & $\begin{array}{l}\text { Single-rooted } \\
\text { teeth }\end{array}$ & $\begin{array}{l}\text { Ultrasonic irrigation system, 30-gauge slot- } \\
\text { tipped needle, EndoVac system, and } \\
\text { erbium-doped yttrium aluminum garnet } \\
\text { laser }\end{array}$ & $\begin{array}{l}\text { Powder mixed } \\
\text { with saline }\end{array}$ & $\begin{array}{l}5 \mathrm{~mL} 5 \% \mathrm{NaOCl} \\
5 \mathrm{~mL} 17 \% \mathrm{c}\end{array}$ & $\begin{array}{l}\text { Electronic } \\
\text { microscope }\end{array}$ & Moderate \\
\hline Kumar et al. [21] & 42 & $\begin{array}{l}\text { Single-rooted } \\
\text { mandibular first } \\
\text { premolars }\end{array}$ & $\begin{array}{l}\text { Endo Activator, EndoVac, ultrasonic } \\
\text { irrigation with Endo-U-File, F-file, and } \\
\text { Maxi-Probe needle }\end{array}$ & Powder & $\begin{array}{l}5 \mathrm{~mL} \text { of } 5.25 \% \mathrm{NaOCl} \\
5 \mathrm{~mL} 17 \% \\
5 \mathrm{~mL} 17 \%\end{array}$ & & Moderate \\
\hline Wang et al. [22] & 20 & $\begin{array}{l}\text { Simulated } \\
\text { curved }\end{array}$ & $\begin{array}{l}\text { Protocol of various methods and irrigant ( } 5 \\
\mathrm{~mL}) \text {, washing following two operating } \\
\text { cycles, needle of 30-gauge NaviTip } \\
\text { [Ultradent] }\end{array}$ & Distilled water & 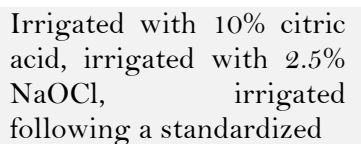 & $\begin{array}{l}\text { Micro-computed } \\
\text { tomography } \\
\text { scanning }\end{array}$ & Moderate \\
\hline $\begin{array}{c}\text { Alturaiki et al. } \\
{[23]}\end{array}$ & 40 & $\begin{array}{l}\text { Single-rooted } \\
\text { teeth }\end{array}$ & $\begin{array}{l}\text { Master apical file, } \\
\text { EndoActivatorand systems }\end{array}$ & Powder & $\begin{array}{l}3 \mathrm{~mL} \text { of } \mathrm{EDTA} 18 \% \text { and } 3 \\
\mathrm{~mL} \text { of } \mathrm{NaOC} 11 \%\end{array}$ & $\begin{array}{l}\text { Scanning electron } \\
\text { microscope }\end{array}$ & Moderate \\
\hline Capar et al. [24] & 88 & $\begin{array}{l}\text { Single-rooted } \\
\text { teeth }\end{array}$ & $\begin{array}{l}\text { Routine syringe irrigation, EndoVac } \\
\text { irrigation, SAF irrigation, and continuous } \\
\text { passive ultrasonic irrigation (PUI) }\end{array}$ & Premixed & $\begin{array}{l}10 \mathrm{~mL} \text { of EDTA } 17 \%+ \\
10 \mathrm{~mL} \text { of } \mathrm{NaOCl} 2.5 \%\end{array}$ & Stereomicroscope & Moderate \\
\hline Yücel et al. [25] & 47 & $\begin{array}{l}\text { Single-rooted } \\
\text { teeth }\end{array}$ & $\begin{array}{l}\text { EndoVac system, needle of } \\
\text { tipped and Pauge slot- } \\
\text { ultrasonic irrigation system }\end{array}$ & Premixed & $\begin{array}{l}5 \mathrm{~mL} \text { of } \mathrm{NaOCl} 5.25 \% \text { and } \\
5 \mathrm{~mL} \text { of EDTA } 17 \%\end{array}$ & $\begin{array}{l}\text { Electron } \\
\text { microscopic images }\end{array}$ & Moderate \\
\hline Baxter et al. [26] & 36 & $\begin{array}{l}\text { First and } \\
\text { second } \\
\text { mandibular } \\
\text { molar mesial } \\
\text { roots }\end{array}$ & $\begin{array}{l}\text { Self-adjusting file }[\mathrm{SAF}] \text {, ultrasonic } \\
\text { irrigation }[\mathrm{PUI}], \text { conventional syringe } \\
\text { irrigation [CSI }] \text { and EndoVac }\end{array}$ & Distilled water & $\begin{array}{l}2 \mathrm{~mL} \text { of a } 1 \% \mathrm{NaOCl} \\
\text { solution, and the final } \\
\text { irrigation was performed } \\
\text { using } 5 \mathrm{~mL} \text { of } \mathrm{NaOCl} \\
5.25 \% \text { and } 5 \mathrm{~mL} \text { of EDTA } \\
17 \%\end{array}$ & $\begin{array}{l}\text { Stereomicroscope } \\
\text { at 30x } \\
\text { magnification }\end{array}$ & Moderate \\
\hline
\end{tabular}

Table 2. Percentage of residual $\mathrm{Ca}(\mathrm{OH}) 2$ residues at every canal.

\begin{tabular}{|c|c|c|c|c|c|c|c|c|}
\hline Author & $\begin{array}{c}\text { Conventional } \\
\text { Irrigation }\end{array}$ & $\begin{array}{l}\text { Ultrasonic } \\
\text { Technique }\end{array}$ & $\begin{array}{c}\text { EndoVac } \\
\text { System }\end{array}$ & YAG Laser & Endo Activator & $\begin{array}{c}\text { Self-adjusting } \\
\text { File }\end{array}$ & $\begin{array}{l}\text { Negative } \\
\text { Pressure }\end{array}$ & Max-i-Probe \\
\hline Kourti et al. [20] & 50.75 & 40.75 & 23.75 & 46.75 & $\mathrm{NA}$ & NA & NA & $\mathrm{NA}$ \\
\hline Kumar et al. [21] & NA & $42.9 \%$ & 38.3 & $\mathrm{NA}$ & 35.2 & 48.2 & NA & 22.9 \\
\hline Wang et al. [22] & 9.86 & 100 & NA & NA & 100 & 99.21 & NA & NA \\
\hline Alturaiki et al. [23] & 80 & 40 & NA & $\mathrm{NA}$ & 60 & NA & 20 & $\mathrm{NA}$ \\
\hline Capar et al. [24] & 10 & 90 & 0 & $\mathrm{NA}$ & $\mathrm{NA}$ & 50 & NA & $\mathrm{NA}$ \\
\hline Yücel et al. [25] & 12 & 70 & 20 & NA & $\mathrm{NA}$ & $\mathrm{NA}$ & $\mathrm{NA}$ & $\mathrm{NA}$ \\
\hline Baxter et al. [26] & 50 & 50 & 15 & $\mathrm{NA}$ & $\mathrm{NA}$ & 52 & NA & $\mathrm{NA}$ \\
\hline
\end{tabular}




\section{Discussion}

Removing intra-canal medicaments from canal systems is crucial for achieving a good sealer and the adherence of root canal fillers to the root canal walls [27]. In the previous study, even though none of the techniques achieved complete calcium hydroxide removal from every third of the tooth, an Er: YAG laser was found to improve the calcium hydroxide removal compared to conventional techniques [20].

The energy, width, and frequency of the pulse, as well as irradiation time and the fiber tip position were found to significantly affect the cleaning efficiency of the laser. The fiber tip is placed close to the groove, a longer irradiation time, a shorter pulse width, higher pulse energy and to a lesser extent, a higher pulse frequency yielded better debris scores. The shape and diameter of the fiber tip were, however, found not to exert statistically significant effects on the obtained results [28]. The previous study showed that EndoVac, EndoActivator, PUI, and F-file to present better results than a conventional side-vented needle [21].

The use of the SAF system in conjunction with EDTA and $\mathrm{NaOCl}$ could improve the elimination of $\mathrm{Ca}(\mathrm{OH})_{2}$ compared to the use of $\mathrm{NaOCl}$ irrigation in conjunction with the SAF. The SAF and continuous PUI can reportedly show higher effectiveness in the elimination of the $\mathrm{Ca}(\mathrm{OH})_{2}$ from standardized artificial grooves in the root canal apex compared to conventional syringe irrigation and EndoVac [24]. The minimum scale values, i.e., the cleanest canals, are associated with the EndoVac and PiezoFlow groups, although these groups were found not to be statistically different. Significantly higher scores were seen in the conventional irrigation group $(\mathrm{p}<0.05)$ [25]. Moreover, despite inefficient conventional needle irrigation in removing root canal $\mathrm{Ca}(\mathrm{OH})_{2}$, PiezoFlow and EndoVac ultrasonic irrigation systems were found to promote both the elimination of intracanal medicaments and the cleaning of the root canal walls.

The PUI effectiveness depends on the duration of the application as well as the delivery of the fresh irrigant to the root canal [18]. Some authors used EndoVac, ProUltra Piezoflow Ultrasonic, and CSI systems to remove the $\mathrm{Ca}(\mathrm{OH})_{2}$. Although the employed systems [i.e., EndoVac and ProUltra Piezoflow Ultrasonic] revealed no significant difference, it was reported that the CSI technique left more root canal $\mathrm{Ca}(\mathrm{OH})_{2}[25]$.

It has been previously shown that the PUI and SAF techniques were more efficient than the CSI, CanalBrush, EndoActivator, and EndoVac approaches in the $\mathrm{Ca}(\mathrm{OH})_{2}$ removal from artificial internal resorption cavities; however, there was no statistically significant difference between the SAF and PUI techniques [29]. Another study compared the SAF, PUI, XP-endo finisher, and CSI techniques for the removal of $\mathrm{Ca}(\mathrm{OH})_{2}$ in teeth with oval canals for which they formed grooves in the apical third. It was found that SAF, PUI, and XP-endo finisher techniques did not significantly differ and the $\mathrm{Ca}(\mathrm{OH})_{2}$ removal amount was the least in the CSI group [30]. In the present study, the SAF technique exhibited significant efficacy in root canal middle third that consistent with more research results.

\section{Conclusion}

This systematic review and meta-analysis showed higher efficacy of SAF and PUI approaches for removing root canal $\mathrm{Ca}(\mathrm{OH})_{2}$. The PUI technique was significantly better for root canal $\mathrm{Ca}(\mathrm{OH})_{2}$ removal, compared to the EndoVac and CSI methods. In addition, the SAF technique showed significant efficacy in the root canal middle third.

\section{Authors' Contributions}

SJ (D) 0000-0003-3803-1235 Conceptualization, Methodology, Investigation, Formal Analysis, Writing Original Draft Preparation and Writing Review and Editing. 


$\begin{array}{lll}\text { GJ } & \text { (D) 0000-0002-5527-9817 } & \begin{array}{l}\text { Formal Analysis, Writing Original Draft Preparation and Writing Review and } \\ \text { Editing. }\end{array} \\ \text { EM } & \text { (D) } 0000-0001-9442-5509 & \text { Writing Review and Editing. } \\ \text { HA } & \text { (D) 0000-0003-1542-2284 } & \text { Writing Review and Editing. } \\ \text { MK } & \text { (D) } 0000-0001-8254-3129 & \text { Writing Review and Editing. } \\ \text { AJ } & \text { (D) } 0000-0001-9895-7457 & \text { Writing-Review and Editing and Visualization. } \\ \text { All authors declare that they contributed to critical review of intellectual content and approval of the final version to be } \\ \text { published. }\end{array}$

\section{Financial Support}

None.

\section{Conflict of Interest}

The authors declare no conflicts of interest.

\section{References}

[1] Ravinanthanan M, Hegde MN, Shetty VA, Kumari S. Antimicrobial assay of combination surfactant irrigant regimen on vancomycin-resistant Enterococcus faecalis. An in vitro direct contact test. Dental Res J 2018; 15(6):397-403.

[2] Athanassiadis B, Abbott P, Walsh LJ. The use of calcium hydroxide, antibiotics and biocides as antimicrobial medicaments in endodontics. Aust Dent J 2007; 52:S64-S82. https://doi.org/10.1111/j.1834-7819.2007.tbo0527.x

[3] Abbott PV. Medicaments: aids to success in endodontics. Part 1. A review of the literature. Aust Dent J 1990; 35(5):438-48. https://doi.org/10.1111/j.1834-7819.1990.tb05427.x

[4] Mohammadi Z, Dummer PMH. Properties and applications of calcium hydroxide in endodontics and dental traumatology. Int Endod J 2011; 44(8):697-730. https://doi.org/10.1111/j.1365-2591.2011.01886.x

[5] Hermann B. Calcium hydroxid als mittelzurn, behandeln und fullen von wurzelkanalen (thesis). Germany: University of Würzburg; 1920. [In German].

[6] Sena IADA, Araújo IJDS, Santos MMD, Lima IPC. Antibacterial effectiveness in vitro of different formulations of calcium hydroxide paste. RGO 2017; 65(4):293-8. https://doi.org/10.1590/1981-863720170002000013127

[7] Estrela C, Estrela CR, Hollanda AC, Decurcio DA, Pécora JD. Influence of iodoform on antimicrobial potential of calcium hydroxide. J Appl Oral Sci 2006; 14(1):33-7. https://doi.org/10.1590/s1678-77572006000100007

[8] Kim D, Kim E. Antimicrobial effect of calcium hydroxide as an intracanal medicament in root canal treatment: a literature review - Part I. In vitro studies. Restor Dent Endod 2014; 39(4):241-52. https://doi.org/10.5395/rde.2014.39.4.241

[9] Oliveira L, Leão M, Carvalho C, Camargo C, Valera M, Jorge A, et al. In vitro effects of calcium hydroxide and polymyxin B on endotoxins in root canals. J Dent 2005; 33(2):107-14. https://doi.org/10.1016/j.jdent.2004.08.008

[10] Radeva EN, Tsanova DM. Efficacy of different endodontic irrigation protocols in calcium hydroxide removal. J IMAB 2016; 22(4):1355-9. https://doi.org/10.5272/jimab.2016224.1355

[11] Rödig T, Vogel S, Zapf A, Hülsmann M. Efficacy of different irrigants in the removal of calcium hydroxide from root canals. Int Endod J 2010; 43(6):519-27. https://doi.org/10.1111/j.1365-2591.2010.01709.x

[12] Plotino G, Pameijer CH, Grande NM, Somma F. Ultrasonics in endodontics: a review of the literature. J Endod 2007; 33(2):81-95. https://doi.org/10.1016/j.joen.2006.10.008

[13] Wiseman A, Cox TC, Paranjpe A, Flake NM, Cohenca N, Johnson JD. Efficacy of sonic and ultrasonic activation for removal of calcium hydroxide from mesial canals of mandibular molars: a microtomographic study. J Endod 2011; 37(2):235-8. https://doi.org/10.1016/j.joen.2010.11.019

[14] Lee SJ, Wu MK, Wesselink P. The effectiveness of syringe irrigation and ultrasonics to remove debris from simulated irregularities within prepared root canal walls. Int Endod J 2004; 37(10):672-8. https://doi.org/10.1111/j.1365-2591.2004.00848.x

[15] Üstün Y, Aslan T, Sağsen B, Dincer AN. The effects of different irrigation protocols on removing calcium hydroxide from the root canals. Niger J Clin Pract 2016; 19(4):465-70. https://doi.org/10.4103/1119-3077.183296

[16] Taşdemir T, Celik D, Er K, Yildirim T, Ceyhanli K, Yeşilyurt C. Efficacy of several techniques for the removal of calcium hydroxide medicament from root canals. Int Endod J 2011; 44:(6):505-9. https://doi.org/10.1111/j.1365-2591.2011.01854.x

[17] Kenee DM, Allemang JD, Johnson JD, Hellstein J, Nichol BK. A quantitative assessment of efficacy of various calcium hydroxide removal techniques. J Endod 2006; 32(6):563-5. https://doi.org/10.1016/j.joen.2005.10.065

[18] Van der Sluis L, Wu M, Wesselink P. The evaluation of removal of calcium hydroxide paste from an artificial standardized groove in the apical root canal using different irrigation methodologies. Int Endod J 2007; 40(1):52-7. https://doi.org/10.1111/j.1365-2591.2006.01182.x 
[19] Ahmetoglu F, Keles A, Simsek N. Effectiveness of the severel irrigation techniques for removal of calcium hydroxidebased intracanal medication from an artificial standardized groove in the apical root canal. Marmara Dent J 2013; $1(2): 53-6$

[20] Kourti E, Pantelidou O. Comparison of different agitation methods for the removal of calcium hydroxide from the root canal: scanning electron microscopy study. J Conserv Dent 2017; 20(6):439-44. https://doi.org/10.4103/JCD.JCD_273_17

[21] Kumar P, de Ataide IdN, Fernandes M, Lambor R. A cone-beam computed tomography assessment of the efficacy of different irrigation devices for removal of silicone oil-based calcium hydroxide from root canal system. J Conserv Dent 2017; 20(2):68-71. https://doi.org/10.4103/0972-0707.212245

[22] Wang Y, Guo LY, Fang HZ, Zou WL, Yang YM, Gao Y, et al. An in vitro study on the efficacy of removing calcium hydroxide from curved root canal systems in root canal therapy. Int J Oral Sci 2017; 9(2):110-6. https://doi.org/10.1038/ijos.2017.14

[23] Alturaiki S, Lamphon H, Edrees H, Ahlquist M. Efficacy of 3 different irrigation systems on removal of calcium hydroxide from the root canal: a scanning electron microscopic study. J Endod 2015; 41(1):97-101. https://doi.org/10.1016/j.joen.2014.07.033

[24] Capar ID, Ozcan E, Arslan H, Ertas H, Aydinbelge HA. Effect of different final irrigation methods on the removal of calcium hydroxide from an artificial standardized groove in the apical third of root canals. J Endod 2014; 4O(3):451-4. https://doi.org/10.1016/j.joen.2013.10.019

[25] Yücel AÇ, Gürel M, Güler E, Karabucak B. Comparison of final irrigation techniques in removal of calcium hydroxide. Aust Endod J 2013; 39(3):1 16-2 1. https://doi.org/10.1111/j.1747-4477.2011.00326.x

[26] Falakaloğlu S, Adıgüzel Ö, Kara M, Yeniçeri Özata M. Efficacy of different irrigation systems used to remove calcium hydroxide from the root canal. J Dent Mater Tech 2019; 8(3):121-8. https://doi.org/10.22038/jdmt.2019.13376

[27] Kim SK, Kim YO. Influence of calcium hydroxide intracanal medication on apical seal. Int Endod J 2002; 35(7):623-8. https://doi.org/10.1046/j.1365-2591.2002.00539.x

[28] George R, Walsh LJ. Apical extrusion of root canal irrigants when using Er: YAG and Er, Cr: YSGG lasers with optical fibers: an in vitro dye study. J Endod 2008; 34(6):706-8. https://doi.org/10.1016/j.joen.2008.03.003

[29] Topçuoğlu H, Düzgün S, Ceyhanlı K, Aktı A, Pala K, Kesim B. Efficacy of different irrigation techniques in the removal of calcium hydroxide from a simulated internal root resorption cavity. Int Endod J 2015; 48(4):309-16. https://doi.org/10.1111/iej.12316

[30] Kfir A, Blau-Venezia N, Goldberger T, Abramovitz I, Wigler R. Efficacy of self-adjusting file, XP-endo finisher and passive ultrasonic irrigation on the removal of calcium hydroxide paste from an artificial standardized groove. Aust Endod J 2018; 44(1):26-31. https://doi.org/10.1111/aej.12204 